\title{
Anticancer effects of ginsenoside Rg3 (Review)
}

\author{
MENGYAO SUN ${ }^{1,2}$, YING YE $^{1}$, LING XIAO $^{1}$, XINYA DUAN $^{1}$, YONGMING ZHANG $^{3}$ and HONG ZHANG ${ }^{1,2}$ \\ ${ }^{1}$ Central Laboratory, Seventh People's Hospital of Shanghai University of TCM, Shanghai 200137; \\ ${ }^{2}$ Department of Pharmaceutical Botany, School of Pharmacy, The Second Military Medical University, Shanghai 200433; \\ ${ }^{3}$ Department of Cardiothoracic Surgery, Shanghai Pudong New District Zhoupu Hospital, Shanghai 201318, P.R. China
}

Received December 31, 2015; Accepted October 20, 2016

DOI: $10.3892 /$ ijmm.2017.2857

\begin{abstract}
Cancer is a life-threatening disease with an alarmingly increased annual mortality rate globally. Although various therapies are employed for cancer, the final effect is not satisfactory. Chemotherapy is currently the most commonly used treatment option. However, the unsatisfactory efficacy, severe side-effects and drug resistance hinder the therapeutic efficacy of chemotherapeutic drugs. There is increasing evidence indicating that ginsenoside $\mathrm{Rg} 3$, a naturally occurring phytochemical, plays an important role in the prevention and treatment of cancer. The suggested mechanisms mainly include the induction of apoptosis, and the inhibition of proliferation, metastasis and angiogenesis, as well as the promotion of immunity. In addition, ginsenoside $\operatorname{Rg} 3$ can be used as an adjuvant to conventional cancer therapies, improving the efficacy and/or reducing adverse effects via synergistic activities. Ginsenoside $\operatorname{Rg} 3$ may be a widely applied natural medicine against cancer. To date however, there is no systematic summary available of the anticancer effects of ginsenoside $\mathrm{Rg} 3$. Therefore, in this review, all available literature over the past 10 years was reviewed and discussed in order to facilitate further research of ginsenoside Rg3.
\end{abstract}

\section{Contents}

1. Introduction

2. Chemical structure

3. Effects of $\mathrm{Rg} 3$ in cancer models

4. Suggested mechanisms of action of $\operatorname{Rg} 3$

5. Clinical studies

6. Conclusions

Correspondence to: Dr Hong Zhang, Central Laboratory, Seventh People's Hospital of Shanghai University of TCM, 358 Datong Road, Shanghai 200137, P.R. China

E-mail: hqzhang51@126.com

Dr Yongming Zhang, Department of Cardiothoracic Surgery, Shanghai Pudong New District Zhoupu Hospital, 1500 Zhouyuan Road, Shanghai 201318, P.R. China

E-mail: 820181402@qq.com

Key words: Panax ginseng, ginsenoside $\mathrm{Rg} 3$, natural product, tumor, adjuvant

\section{Introduction}

Cancer, characterized by uncontrolled cell growth, is considered to be the second leading cause of mortality (30\% of total mortality) worldwide, which seriously threatens public health (1). A report released by the World Health Organization on the global situation of cancer in 2012 indicated that the annual new cancer cases reached 14,000,000 globally, with $8,200,000$ deaths, and the number of new cases is expected to increase to $24,000,000$ in the year 2035 (2). The global cancer burden is currently growing at an alarming rate, and there is no effective available treatment to date to curb the spread of cancer.

At present, the clinical management of cancer always involves several conventional modalities. Surgical resection is an effective method for the treatment of tumors in the early stages and for the clinical treatment of local tumors. However, surgery is often ineffective once tumors have spread or are diagnosed at an advanced and/or late stage of the disease. The prognosis remains poor due to tumor recurrence, diffusion and even metastasis following surgery (3). Radiotherapy is more effective than surgery in many cases. However, its application is limited by tumor metastasis and various side-effects. Recently, biotherapies such as immunotherapy, gene therapy and monoclonal antibody therapy have become a hotspot and provide a new method with which to prevent and treat tumors. Since many aspects are still unclear, tumor biotherapy has not been widely used (4). Chemotherapy is currently the most commonly used treatment option for cancer. However, the administration of traditional chemotherapeutic agents at high doses always induce significant non-selective toxicities, such as a reduction in bone density and immunosuppression, while low or moderate doses of these agents usually does not exert significant antitumor effects (5); in addition, there is the issue of acquired drug resistance. Therefore, the development of novel agents which can selectively induce cancer cell death without threatening normal cells is of utmost importance.

It has been generally recognized that natural products play a unique therapeutic role in the treatment of a number of diseases. Ginseng, the root of Panax ginseng C.A. Meyer, has been widely used in East Asia countries for thousands years as a natural tonic (6). Ginsenosides, extracted from Panax ginseng C.A. Meyer, are the main active components with a wide range of pharmacological activities. More than 100 types of ginsenosides have been isolated and determined 


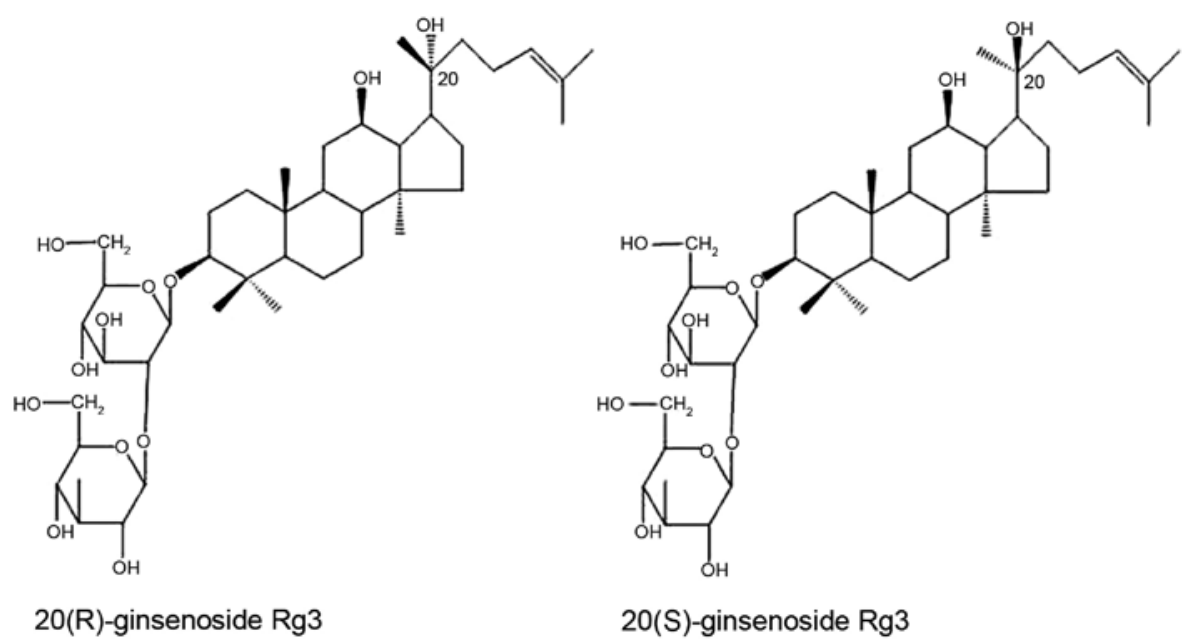

Figure 1. Chemical structures of 20(R)-ginsenoside Rg3 and 20(S)-ginsenoside Rg3.

from ginseng (7). Among these ginsenosides, ginsenoside $\operatorname{Rg} 3$ has been shown to have significant physiological activites (8), such as hepatoprotection, neuroprotection, cardiovascularprotection, promotion of immunity, as well as anti-fatigue, antioxidant, and most importantly, antitumor effects (9-14). There is increasing evidence indicating that ginsenoside $\mathrm{Rg} 3$ exerts antitumor effects in a number of cancer models, such as lung, liver and breast cancer (15-17). Furthermore, ginsenoside $\operatorname{Rg} 3$ may be a beneficial supplement, and the combined administration of ginsenoside $\operatorname{Rg} 3$ and conventional chemotherapeutic drugs may be more effective than either one being administered alone. The use of ginsenoside $\mathrm{Rg} 3$ in cancer therapy may aid in the prevention of toxicity and morbidity associated with conventional chemotherapy, even though the underlying mechanisms have not yet been fully elucidated (18). Thus, in this review, we aimed to provide a systematic summary on the cancer-preventive effects of ginsenoside $\mathrm{Rg} 3$.

\section{Chemical structure}

Ginsenoside $\operatorname{Rg} 3$ is a type of tetracyclic triterpenoid saponin, rich in red ginseng. The major ginsenosides, such as Rb1, Rb2, and $\mathrm{Rd}$ can be readily converted into ginsenoside $\mathrm{Rg} 3$, the production of which may increase from 0.37 to $1.32 \%$ (w/w) by heating (19). Due to the different spatial structures from $\mathrm{C} 20$ positions, there are two enantiomers, $20(R)$ and 20(S)-isomer (Fig. 1) (20). With differential configuration, their antitumor activities exhibit certain differences (21).

\section{Effects of Rg3 in cancer models}

Natural products have always been a very good source of drugs against cancer and have gained much attention lately. For example, paclitaxel is one of the most important antitumor natural agents isolated from the bark of Pacific yew tree (22). A study carried out in 1978 demonstrated the inhibition or prevention of carcinogenesis induced by various chemical carcinogens for ginseng (23). Ginsenoside $\mathrm{Rg} 3$ has been found to be an effective ingredient contributing to the anticarcinogenic activity of ginseng. To provide a summary of the antitumor effects of ginsenoside $\operatorname{Rg} 3$, we collected data from previous scientific studies published over the last 10 years. Ginsenoside $\operatorname{Rg} 3$ has been shown to possess significant anticancer activity and it may be used alone (Table I) or as a supplement to chemotherapeutic drugs in order to improve the therapeutic efficacy and minimize or eliminate drug-induced toxicity and chemotherapeutic resistance (Table II).

Treatment with $\operatorname{Rg} 3$ significantly has been shown to inhibit the growth of cancer in various cancer models. Ginsenoside Rg3 has been shown to exert cancer-preventive effects in both in vitro and in vivo studies in a dose- and time-dependent manner. The protective effects of $\mathrm{Rg} 3$ are mainly related to the induction of apoptosis, and the inhibition of proliferation, metastasis and angiogenesis (Table I). Table II displays the combined treatment effects of both $\operatorname{Rg} 3$ and several existing chemical drugs on cancer models. Ginsenoside Rg3 has been shown to enhance the antitumor effects of conventional chemotherapeutic agents and to reduce drug-induced toxicity and chemotherapeutic resistance in vitro and in vivo. Combination therapies using chemotherapeutic agents and ginsenoside may be an innovative and promising therapeutic strategy for the treatment of human cancer. However,the pharmacodynamic interactions between chemotherapeutic drugs and $\mathrm{Rg} 3$ warrant further investigation.

In addition, the hepatic arterial administration of $\mathrm{Rg} 3$ combined with local transarterial embolization (TAE) was shown to more effectively inhibited VX2 liver tumor growth than any mono-therapies, with the inhibition of angiogenesis and the induction of caspase-dependent apoptosis (24).

\section{Suggested mechanisms of action of $\mathrm{Rg3}$}

Cancer is a class of diseases involving genetic damage which alters several intracellular biochemical signals and eventually results in uncontrolled cell growth (25). Drugs with antitumor activity, such as $\operatorname{Rg} 3$ may be able to alter these abnormal alterations through certain mechanisms. Although the anticancer activities of Rg3 have been widely investigated, the exact molecular mechanisms are not yet clear. The possible mechanisms of action of $\mathrm{Rg} 3$ based on the existing studies are described as follows: 
Table I. Summary of the anticancer activities of ginsenoside $\operatorname{Rg} 3$.

\begin{tabular}{|c|c|c|}
\hline Cancer & Ginsenoside Rg3 & Observation \\
\hline $\begin{array}{l}\text { Breast } \\
\text { cancer }\end{array}$ & $\operatorname{Rg} 3$ & $\begin{array}{l}\text { In vitro } \\
(30 \mu \mathrm{M})\end{array}$ \\
\hline $\begin{array}{l}\text { Breast } \\
\text { cancer }\end{array}$ & $\begin{array}{l}20(S) \text {-ginsenoside } \\
\text { Rg3 }\end{array}$ & $\begin{array}{l}\text { In vitro } \\
(100-300 \mu \mathrm{M})\end{array}$ \\
\hline $\begin{array}{l}\text { Breast } \\
\text { cancer }\end{array}$ & $\begin{array}{l}20(S) \text {-ginsenoside } \\
\text { Rg3 }\end{array}$ & $\begin{array}{l}\text { In vitro } \\
(20-60 \mu \mathrm{g} / \mathrm{ml})\end{array}$ \\
\hline $\begin{array}{l}\text { Colon } \\
\text { cancer }\end{array}$ & $\begin{array}{l}20(S) \text {-ginsenoside } \\
\operatorname{Rg} 3\end{array}$ & $\begin{array}{l}\text { In vitro } \\
(10-100 \mu \mathrm{M})\end{array}$ \\
\hline
\end{tabular}

$\begin{array}{cl}\text { Cell type } & \text { Effects } \\ \text { MDA-MB-231 } & \begin{array}{l}\text { Induction of } \\ \text { apoptosis }\end{array}\end{array}$

Mechanisms of action

Refs.

$\begin{array}{lll}\text { Colon } & 20(S) \text {-ginsenoside } & \text { In vitro } \\ \text { cancer } & \operatorname{Rg} 3 & (\geq 100 \mu \mathrm{M})\end{array}$

$\begin{array}{ll}\text { MCF-7 } & \text { Inhibition of } \\ \text { MDA-MB-231 } & \text { proliferation } \\ \text { MDA-MB-231 } & \begin{array}{l}\text { Inhibition of } \\ \text { metastasis }\end{array} \\ \text { HT-29 } & \begin{array}{l}\text { Inhibition of } \\ \text { proliferation, } \\ \text { induction of } \\ \text { apoptosis }\end{array}\end{array}$

HT-29

$\begin{array}{llll}\begin{array}{l}\text { Colon } \\ \text { cancer }\end{array} & \begin{array}{l}\text { 20(S)-ginsenoside } \\ \operatorname{Rg} 3\end{array} & \begin{array}{l}\text { In vitro } \\ (100-300 \mu \mathrm{M})\end{array} & \text { HCT116 } \\ & & & \\ \text { Colon } & \operatorname{Rg} 3 & \begin{array}{l}\text { In vitro } \\ \text { (above } 100 \mu \mathrm{M})\end{array} & \text { HCT116 } \\ \text { cancer } & & \text { SW } 480 \\ & & (20 \mathrm{mg} / \mathrm{kg}) & \\ & & \end{array}$

$\begin{array}{lll}\text { Colon } & \operatorname{Rg} 3 & \text { In vitro } \\ \text { cancer } & & (200 \mu \mathrm{M})\end{array}$

\begin{tabular}{|c|c|c|c|c|}
\hline $\begin{array}{l}\text { Esophageal } \\
\text { carcinoma } \\
\text { Renal } \\
\text { cancer }\end{array}$ & $\operatorname{Rg} 3$ & $\begin{array}{l}\text { In vitro } \\
(25-200 \mu \mathrm{M})\end{array}$ & $\begin{array}{l}\text { Eca-109 } \\
786-0\end{array}$ & $\begin{array}{l}\text { Inhibition of } \\
\text { proliferation } \\
\text { and angiogenesis }\end{array}$ \\
\hline Gallbladder & $\begin{array}{l}\text { 20(S)-ginsenoside } \\
\text { Rg3 }\end{array}$ & $\begin{array}{l}\text { In vitro } \\
(25-400 \mu \mathrm{M}) \\
\text { in vivo } \\
(20 \text { and } 40 \mathrm{mg} / \mathrm{kg})\end{array}$ & $\begin{array}{l}\text { GBC-SD } \\
\text { NOZ }\end{array}$ & $\begin{array}{l}\text { Cycle arrest, } \\
\text { induction of } \\
\text { apoptosis, } \\
\text { inhibition of the } \\
\text { growth of } \\
\text { xenografts }\end{array}$ \\
\hline Gallbladder & $\operatorname{Rg} 3$ & $\begin{array}{l}\text { In vitro } \\
(10-100 \mu \mathrm{g} / \mathrm{ml}) \\
\text { in vivo } \\
(20 \mathrm{mg} / \mathrm{kg})\end{array}$ & $\begin{array}{l}\text { GBC-SD } \\
\text { QBC939 } \\
\text { Mz-ChA-1 }\end{array}$ & $\begin{array}{l}\text { Induction of } \\
\text { apoptosis, } \\
\text { inhibition of } \\
\text { the growth of } \\
\text { tumor } \\
\text { xenografts }\end{array}$ \\
\hline
\end{tabular}

Inhibition of mutant p53

and NF- $\mathrm{KB}$ signaling via possibly inactivation of ERK and Akt to activate mitochondrial death pathway

Arrested the cells in the G1-phase

Inhibition of the expression of CXCR4

Activation of caMKK $\beta /$ AMPK mediated apoptosis mainly by regulating the mitochondrial pathway involving $\mathrm{p} 53 / \mathrm{Bcl}-2 / \mathrm{Bax} /$ cytochrome $c /$ caspase-3, caspase-9/PARP

Inhibition of proliferation, induction of apoptosis

Reduced PCNA, STRAP and other protein related to mitosis and DNA repair, downregulated Rho-GDI while upregulated TM1, GSTP1 and Annexin

Mostly by regulating the proliferation Eph/ephrin pathway and gene expression of AKAPA8L and PITPNA

Inhibition of Blocked the nuclear proliferation, inhibition of tumor growth in xenograft model translocation of $\beta$-catenin and then inhibited $\beta$-catenin/Tcf signal pathway

Inhibited $\mathrm{NF}-\kappa \mathrm{B}$ signaling metastasis

pathway and the

NF- $\kappa B$-regulated gene

expression such as c-Myc, COX-2 and MMP-9

\section{Suppressed VEGF} expression by blocking multiple signaling pathways including HIF- $1 \alpha$, COX-2, NF- $\kappa$ B, STAT3 and MAPKs

Suppressed MDM2

to activate the p53 pathway, induced cycle arrest at $\mathrm{G}_{0} / \mathrm{G}_{1}$ and mitochondrial-dependent apoptosis

Activation of ER stress to regulate apoptosis related proteins such as caspase-12, CHOP 
Table I. Continued.

\begin{tabular}{|c|c|c|c|c|c|c|}
\hline Cancer & Ginsenoside Rg3 & Observation & Cell type & Effects & Mechanisms of action & Refs. \\
\hline $\begin{array}{l}\text { Gastric } \\
\text { cancer }\end{array}$ & $\begin{array}{l}\text { 20(S)-ginsenoside } \\
\text { Rg3 }\end{array}$ & $\begin{array}{l}\text { In vitro } \\
(25-100 \mu \mathrm{M})\end{array}$ & AGS & $\begin{array}{l}\text { Induction of } \\
\text { apoptosis, inhibition } \\
\text { of proliferation }\end{array}$ & $\begin{array}{l}\text { Upregulation of caspase- } 3 \text {, } \\
\text { caspase- } 8 \text {, caspase- } 9 \text { and } \\
\text { Bax while downregulation } \\
\text { of Bcl-2 }\end{array}$ & (32) \\
\hline $\begin{array}{l}\text { Gastric } \\
\text { cancer }\end{array}$ & $\operatorname{Rg} 3$ & $\begin{array}{l}\text { In vitro } \\
(50 \mu \mathrm{g} / \mathrm{ml})\end{array}$ & SGC-7901 & $\begin{array}{l}\text { Induction of } \\
\text { apoptosis }\end{array}$ & $\begin{array}{l}\text { Inhibition of the expression } \\
\text { of FUT4 via SP1 and HSF1 } \\
\text { transcriptional regulation } \\
\text { and eventually, activation of } \\
\text { caspase- } 3 \text {, caspase- } 8 \\
\text { and caspase- } 9\end{array}$ & (37) \\
\hline $\begin{array}{l}\text { Gastric } \\
\text { cancer }\end{array}$ & $\operatorname{Rg} 3$ & $\begin{array}{l}\text { In vitro } \\
(200-500 \mu \mathrm{M})\end{array}$ & AGS & $\begin{array}{l}\text { Induction of } \\
\text { apoptosis }\end{array}$ & $\begin{array}{l}\text { Blocked TRPM7 } \\
\text { channel activity }\end{array}$ & (39) \\
\hline $\begin{array}{l}\text { Glioblastoma } \\
\text { multiforme }\end{array}$ & $\operatorname{Rg} 3$ & $\begin{array}{l}\text { In vitro } \\
(\geq 10 \mu \mathrm{M})\end{array}$ & U87MG & $\begin{array}{l}\text { Induction of } \\
\text { apoptosis }\end{array}$ & $\begin{array}{l}\text { Suppression of MEK/ } \\
\text { MAPK signaling pathway, } \\
\text { activation of ROS by } \\
\text { antioxidant enzyme system }\end{array}$ & (30) \\
\hline Glioma & $\begin{array}{l}20(S) \text {-ginsenoside } \\
\text { Rg3 }\end{array}$ & $\begin{array}{l}\text { In vitro } \\
(20 \mu \mathrm{M})\end{array}$ & U87 & $\begin{array}{l}\text { Inhibition of } \\
\text { proliferation }\end{array}$ & $\begin{array}{l}\text { Induced cell senescence } \\
\text { by activating Akt and } \\
\text { p53/p21 dependent } \\
\text { signaling pathways }\end{array}$ & $(45)$ \\
\hline $\begin{array}{l}\text { Lung } \\
\text { cancer }\end{array}$ & $\operatorname{Rg} 3$ & $\begin{array}{l}\text { In vitro } \\
(50-100 \mu \mathrm{M}) \\
\text { in vivo } \\
(30 \mathrm{mg} / \mathrm{kg})\end{array}$ & A549 & $\begin{array}{l}\text { Induction of } \\
\text { apoptosis, inhibition } \\
\text { of proliferation, } \\
\text { inhibition of } \\
\text { tumor growth }\end{array}$ & $\begin{array}{l}\text { Inhibited EGFR activation } \\
\text { and its downstream signal } \\
\text { transduction, induced } \\
\text { caspase-dependent } \\
\text { apoptotic pathway }\end{array}$ & $(15)$ \\
\hline $\begin{array}{l}\text { Lung } \\
\text { cancer }\end{array}$ & $\begin{array}{l}20(R) \text {-ginsenoside } \\
\text { Rg3 }\end{array}$ & $\begin{array}{l}\text { In vitro } \\
(25 \text { and } 50 \mu \mathrm{g} / \mathrm{ml})\end{array}$ & A549 & $\begin{array}{l}\text { Inhibition of } \\
\text { metastasis }\end{array}$ & $\begin{array}{l}\text { Inhibited TGF- } \beta 1 \text { induced } \\
\text { EMT via downregulation } \\
\text { of Snail and inactivation } \\
\text { of MMP-2, p38 MAPK } \\
\text { and Smad2 }\end{array}$ & (53) \\
\hline $\begin{array}{l}\text { Liver } \\
\text { cancer }\end{array}$ & $\begin{array}{l}20(S) \text {-ginsenoside } \\
\text { Rg3 }\end{array}$ & $\begin{array}{l}\text { In vitro } \\
(\geq 10 \mu \mathrm{M})\end{array}$ & Hep3B & $\begin{array}{l}\text { Induction of } \\
\text { apoptosis }\end{array}$ & $\begin{array}{l}\text { Upregulation of ROS, Bax, } \\
\text { the release of cytochrome } c \\
\text { and caspase- } 3 \text {, down- } \\
\text { regulation of Bcl-2, MMP }\end{array}$ & (16) \\
\hline $\begin{array}{l}\text { Liver } \\
\text { cancer }\end{array}$ & $\operatorname{Rg} 3$ & $\begin{array}{l}\text { In vitro } \\
(50-200 \mu \mathrm{g} / \mathrm{ml}) \\
\text { in vivo } \\
(3.0 \mathrm{mg} / \mathrm{kg})\end{array}$ & $\begin{array}{l}\text { Hep1-6 } \\
\text { HepG2 }\end{array}$ & $\begin{array}{l}\text { Induction of } \\
\text { apoptosis, inhibition } \\
\text { of tumor growth } \\
\text { and increased } \\
\text { survival time of } \\
\text { tumor-bearing mice }\end{array}$ & $\begin{array}{l}\text { Decrease of Bcl- } 2 \text { and } \\
\text { Bcl-xL while increase of } \\
\text { Bax, caspase- } 3 \text { and the } \\
\text { release of cytochrome } c\end{array}$ & (29) \\
\hline $\begin{array}{l}\text { Liver } \\
\text { cancer }\end{array}$ & $\operatorname{Rg} 3$ & $\begin{array}{l}\text { In vitro } \\
(25-100 \mu \mathrm{g} / \mathrm{ml})\end{array}$ & $\begin{array}{l}\text { SMMC-7721 } \\
\text { HepG2 }\end{array}$ & $\begin{array}{l}\text { Inhibition of } \\
\text { proliferation, } \\
\text { induction of } \\
\text { apoptosis }\end{array}$ & $\begin{array}{l}\text { Induction of caspase- } \\
\text { dependent endogenous } \\
\text { apoptotic pathway }\end{array}$ & (33) \\
\hline Melanoma & $\begin{array}{l}20(R) \text {-ginsenoside } \\
\text { Rg3 }\end{array}$ & $\begin{array}{l}\text { In vitro } \\
(25-100 \mu \mathrm{g} / \mathrm{ml}) \\
\text { in vivo } \\
(20 \mathrm{mg} / \mathrm{kg})\end{array}$ & A 375 & $\begin{array}{l}\text { Inhibition of, } \\
\text { proliferation } \\
\text { inhibition of } \\
\text { the growth of } \\
\text { tumor xenografts }\end{array}$ & $\begin{array}{l}\text { Reduction of FUT4 } \\
\text { and LeY to inhibit } \\
\text { EGFR/MAPK } \\
\text { signaling pathway }\end{array}$ & $(41)$ \\
\hline Melanoma & $\begin{array}{l}\text { 20(R)-ginsenoside } \\
\text { Rg3 }\end{array}$ & $\begin{array}{l}\text { In vitro } \\
(50 \mu \mathrm{g} / \mathrm{ml}) \\
\text { in vivo } \\
(20 \mathrm{mg} / \mathrm{kg})\end{array}$ & $\begin{array}{l}\text { A } 375 \\
\text { C8161 }\end{array}$ & $\begin{array}{l}\text { Inhibition of } \\
\text { proliferation, } \\
\text { inhibition of } \\
\text { xenograft tumor } \\
\text { volume and } \\
\text { weight }\end{array}$ & $\begin{array}{l}\text { Decreased the expression } \\
\text { of HDAC } 3 \text {, increasing } \\
\text { p53 acetylation and } \\
\text { transcription activity, } \\
\text { induced cell cycle } \\
\text { arrest at } \mathrm{G}_{0} / \mathrm{G}_{1}\end{array}$ & (47) \\
\hline
\end{tabular}


Table I. Continued.

\begin{tabular}{|c|c|c|c|c|c|c|}
\hline Cancer & Ginsenoside Rg3 & Observation & Cell type & Effects & Mechanisms of action & Refs. \\
\hline Melanoma & $\begin{array}{l}20(S) \text {-ginsenoside } \\
\operatorname{Rg} 3\end{array}$ & $\begin{array}{l}\text { In vitro } \\
(40-100 \mu \mathrm{g} / \mathrm{ml}) \\
\text { in vivo } \\
(1.5 \mathrm{mg} / \mathrm{kg})\end{array}$ & B16 & $\begin{array}{l}\text { Inhibition of } \\
\text { proliferation, induction of } \\
\text { apoptosis, inhibition of } \\
\text { metastasis, increased } \\
\text { the survival time }\end{array}$ & $\begin{array}{l}\text { Regulation of } \\
\text { cell cycle and the } \\
\text { expression of caspase } \\
\text { and Bcl-2, inhibition } \\
\text { of angiogenesis }\end{array}$ & $(31)$ \\
\hline Melanoma & $\begin{array}{l}20(S) \text {-ginsenoside } \\
\text { Rg3 }\end{array}$ & $\begin{array}{l}\text { In vitro } \\
(25-100 \mu \mathrm{M})\end{array}$ & $\mathrm{B} 16 \mathrm{~F} 10$ & $\begin{array}{l}\text { Inhibition of } \\
\text { metastasis }\end{array}$ & $\begin{array}{l}\text { Inhibited MMP-13 } \\
\text { expression by the } \\
\text { p38 MAPK signaling } \\
\text { pathway }\end{array}$ & $(51)$ \\
\hline $\begin{array}{l}\text { Ovarian } \\
\text { cancer }\end{array}$ & $\begin{array}{l}20(S) \text {-ginsenoside } \\
\operatorname{Rg} 3\end{array}$ & $\begin{array}{l}\text { In vitro } \\
\text { in vivo }\end{array}$ & $\begin{array}{l}\mathrm{SKOV}-3 \\
(160 \mu \mathrm{g} / \mathrm{ml}) \\
3 \mathrm{AO} \\
(80 \mu \mathrm{g} / \mathrm{ml})\end{array}$ & $\begin{array}{l}\text { Induction of } \\
\text { apoptosis, } \\
\text { inhibition of proliferation, } \\
\text { inhibition of the growth } \\
\text { of tumor xenografts }\end{array}$ & $\begin{array}{l}\text { Suppression of } \\
\text { Warburg effect } \\
\text { though the STAT3/HK2 } \\
\text { pathway }\end{array}$ & (91) \\
\hline $\begin{array}{l}\text { Ovarian } \\
\text { cancer }\end{array}$ & $\begin{array}{l}20(S) \text {-ginsenoside } \\
\operatorname{Rg} 3\end{array}$ & $\begin{array}{l}\text { In vitro } \\
(25-100 \mu \mathrm{g} / \mathrm{ml})\end{array}$ & HO-8910 & $\begin{array}{l}\text { Induction of } \\
\text { apoptosis }\end{array}$ & $\begin{array}{l}\text { Regulation of } \\
\text { PI3K/Akt and XIAP } \\
\text { pathways to activate } \\
\text { caspase-3 and caspase-9 }\end{array}$ & $(28)$ \\
\hline $\begin{array}{l}\text { Ovarian } \\
\text { cancer }\end{array}$ & $\begin{array}{l}20(S) \text {-ginsenoside } \\
\operatorname{Rg} 3\end{array}$ & $\begin{array}{l}\text { In vitro } \\
\text { in vivo } \\
(5 \mathrm{mg} / \mathrm{kg})\end{array}$ & $\begin{array}{l}\mathrm{SKOV}-3 \\
(80 \mu \mathrm{g} / \mathrm{ml}) \\
3 \mathrm{AO} \\
(160 \mu \mathrm{g} / \mathrm{ml})\end{array}$ & $\begin{array}{l}\text { Inhibition of metastasis, } \\
\text { inhibition of tumor } \\
\text { growth and metastasis }\end{array}$ & $\begin{array}{l}\text { Blocked } \\
\text { hypoxia-induced } \\
\text { EMT by decreasing } \\
\text { HIF-1 } \alpha \text { expression }\end{array}$ & $(54)$ \\
\hline $\begin{array}{l}\text { Ovarian } \\
\text { cancer }\end{array}$ & $\operatorname{Rg} 3$ & $\begin{array}{l}\text { In vitro } \\
(2.5,5.0 \mu \mathrm{g} / \mathrm{ml}) \\
\text { in vivo } \\
(0.3-3 \mathrm{mg} / \mathrm{kg})\end{array}$ & SKOV-3 & $\begin{array}{l}\text { Inhibition of metastasis, } \\
\text { and angiogenesis, } \\
\text { inhibition of lung } \\
\text { metastasis of } \\
\text { ovarian cancer }\end{array}$ & $\begin{array}{l}\text { Inhibition of } \\
\text { angiogenesis, tumor } \\
\text { cell invasive ability, } \\
\text { as well as the } \\
\text { expression of MMP-9 }\end{array}$ & $(50)$ \\
\hline $\begin{array}{l}\text { Pancreatic } \\
\text { cancer }\end{array}$ & $\operatorname{Rg} 3$ & $\begin{array}{l}\text { In vitro } \\
(25-200 \mu \mathrm{M}) \\
\text { in vivo } \\
(5,10,20 \mathrm{mg} / \mathrm{kg})\end{array}$ & SW-1990 & $\begin{array}{l}\text { Inhibition of VM } \\
\text { and the growth of } \\
\text { tumor xenografts }\end{array}$ & $\begin{array}{l}\text { Inhibition of } \\
\text { the expression of } \\
\text { particular genes } \\
\text { including VE-cadherin, } \\
\text { EphA2, MMP-2 } \\
\text { and MMP-9 }\end{array}$ & $(60)$ \\
\hline $\begin{array}{l}\text { Prostate } \\
\text { cancer }\end{array}$ & $\begin{array}{l}\text { 20(S)-ginsenoside } \\
\text { Rg3 }\end{array}$ & $\begin{array}{l}\text { In vitro } \\
\text { (above } 100 \mu \mathrm{M})\end{array}$ & $\begin{array}{l}\mathrm{PC} 3 \\
\mathrm{LNCaP}\end{array}$ & $\begin{array}{l}\text { Inhibition of } \\
\text { proliferation }\end{array}$ & $\begin{array}{l}\text { Inhibition of DNA } \\
\text { synthesis and cancer } \\
\text { cells attachment, } \\
\text { regulation of three } \\
\text { MAP kinase activity, } \\
\text { including ERKs, p38 } \\
\text { MAP kinases and JNK }\end{array}$ & $(40)$ \\
\hline $\begin{array}{l}\text { Prostate } \\
\text { cancer }\end{array}$ & $\begin{array}{l}\text { 20(S)-ginsenoside } \\
\operatorname{Rg} 3\end{array}$ & $\begin{array}{l}\text { In vitro } \\
(1 \text { and } 10 \mu \mathrm{M})\end{array}$ & PC-3M & $\begin{array}{l}\text { Inhibition of } \\
\text { migration }\end{array}$ & $\begin{array}{l}\text { Transcriptionally } \\
\text { inhibited the } \\
\text { expression of AQP1 } \\
\text { via the p38 MAPK pathway }\end{array}$ & $\begin{array}{l}(55) \\
y\end{array}$ \\
\hline
\end{tabular}

NF-kB, nuclear factor-кB; ERK, extracellular signal-regulated kinase; PARP, poly (ADP-ribose) polymerase; PCNA, proliferating cell nuclear antigen; STRAP, serine/threonine kinase receptor associated protein; AKAPA8L, A-kinase (PRKA) anchor protein 8-like; PITPNA, phosphatidylinositol transfer protein $\alpha$; COX-2, cyclooxygenase-2; MMP-2, matrix metalloproteinase 2; HIF-1 $\alpha$, hypoxia-inducible factor-1; ROS, reactive oxygen species; STAT3, signal transducer and activator of transcription 3; HK2, hexokinase 2; p38 MAPK, p38 mitogen activated protein kinase; MDM2, murine double minute 2; ER, endoplasmic reticulum; CHOP, C/EBP homologous protein; FUT4/LeY, fucosyltransferase IV/Lewis Y; HSF1, heat shock factor protein 1; SP1, specificity protein 1; TRPM7, transient receptor potential melastatin 7; EGFR, epidermal growth factor receptor; TGF- $\beta 1$ : transforming growth factor- $\beta 1$; MMP, mitochondrial membrane potential; HDAC3, histone deacetylase 3 ; AMPK, AMP-activated protein kinase; EMT, epithelial-mesenchymal transition; PI3, phosphoinositide-3-kinase; CXCR4, CXC receptor 4; VM, vasculogenic mimicry; VEGF, vascular endothelial growth factor; VE-cadherin, vascular endothelial-cadherin; EphA2, epithelial cell kinase; $\mathrm{AQP1}$, aquaporin 1. 
Table II. Combination therapy with ginsenoside $\operatorname{Rg} 3$ and conventional chemotherapeutic drugs.

\begin{tabular}{|c|c|c|c|c|c|c|}
\hline Drug & Cancer & Observation & Cell type & Activity & Mechanisms & Refs \\
\hline $\mathrm{As}_{2} \mathrm{O}_{3}$ & $\begin{array}{l}\text { Lung } \\
\text { cancer }\end{array}$ & $\begin{array}{l}\text { In vitro } \\
\text { in vivo }\end{array}$ & NCI-H1299 & $\begin{array}{l}\text { Enhanced the antitumor } \\
\text { efficacy, prolonged the } \\
\text { survival time of tumor- } \\
\text { bearing mice }\end{array}$ & $\begin{array}{l}\text { Promoted } \\
\text { proliferation } \\
\text { inhibition and } \\
\text { apoptosis induction }\end{array}$ & (62) \\
\hline Cisplatin & $\begin{array}{l}\text { Bladder } \\
\text { cancer }\end{array}$ & In vitro & $\mathrm{T} 24 \mathrm{R} 2$ & $\begin{array}{l}\text { Enhanced the } \\
\text { antitumor activity }\end{array}$ & $\begin{array}{l}\text { Stimulated cell } \\
\text { arrest at } \mathrm{G} 2 / \mathrm{M} \text {, } \\
\text { activated intrinsic } \\
\text { apoptotic pathway }\end{array}$ & (61) \\
\hline Cisplatin & $\begin{array}{l}\text { Colon } \\
\text { cancer }\end{array}$ & In vivo & & $\begin{array}{l}\text { Augmented the } \\
\text { anti-neoplastic activity } \\
\text { of cisplatin, decreased } \\
\text { cisplatin-induced tissue } \\
\text { damage in the kidney } \\
\text { and liver, inhibited } \\
\text { resistance to } \\
\text { chemotherapeutics }\end{array}$ & $\begin{array}{l}\text { Reduction of the } \\
\text { level of nuclear Nrf2, } \\
\text { HO-1/NQO-1 and ROS }\end{array}$ & (72) \\
\hline Cyclophosphamide & & In vivo & & $\begin{array}{l}\text { Suppressed } \\
\text { CP-induced } \\
\text { side effects }\end{array}$ & $\begin{array}{l}\text { Inhibited CP-induced } \\
\text { oxidative stress by } \\
\text { regulating the activities } \\
\text { of SOD and GPx, } \\
\text { and MDA contents }\end{array}$ & (6) \\
\hline Cyclophosphamide & $\begin{array}{l}\text { Ovarian } \\
\text { cancer }\end{array}$ & In vivo & & $\begin{array}{l}\text { Reinforced each other's } \\
\text { antitumor activity, } \\
\text { decreased CP-induced } \\
\text { side-effects }\end{array}$ & Not investigated & (64) \\
\hline Cyclophosphamide & $\begin{array}{l}\text { Lewis lung } \\
\text { cancer }\end{array}$ & In vivo & & $\begin{array}{l}\text { Augmented the antitumor } \\
\text { and anti-angiogenesis } \\
\text { activity, reduced } \\
\text { drug-induced toxicity } \\
\text { and prolonged the } \\
\text { survival time }\end{array}$ & $\begin{array}{l}\text { Inhibited the } \\
\text { expression of Ki-67, } \\
\text { VEGF, Bcl-2 and p53 }\end{array}$ & $(65)$ \\
\hline Docetaxel & $\begin{array}{l}\text { Prostate } \\
\text { cancer }\end{array}$ & In vitro & $\begin{array}{l}\text { LNCaP } \\
\text { PC-3 } \\
\text { DU145 }\end{array}$ & $\begin{array}{l}\text { Augmented susceptibility } \\
\text { of cancer cells } \\
\text { to docetaxel }\end{array}$ & $\begin{array}{l}\text { Inactivation of NF- } \mathrm{NB} \\
\text { and then regulation of } \\
\text { its target gene expression } \\
\text { such as Bax and caspase- } 3\end{array}$ & $(70)$ \\
\hline Docetaxel & $\begin{array}{l}\text { Colon } \\
\text { cancer }\end{array}$ & In vitro & $\begin{array}{l}\text { HCT116 } \\
\text { SW620 }\end{array}$ & $\begin{array}{l}\text { Potentiated sensitivity } \\
\text { of cancer cells } \\
\text { to docetaxel }\end{array}$ & $\begin{array}{l}\text { Inhibition of } \mathrm{NF}-\kappa \mathrm{B} \text { to } \\
\text { regulate the expression } \\
\text { of pro-apoptotic protein } \\
\text { and anti-apoptotic protein }\end{array}$ & (71) \\
\hline Doxorubicin & $\begin{array}{l}\text { Hepatocellular } \\
\text { carcinoma }\end{array}$ & $\begin{array}{l}\text { In vitro } \\
\text { In vivo }\end{array}$ & $\begin{array}{l}\text { SK-Hep1 } \\
\text { HepG2 } \\
\text { Huh-7 } \\
\text { Hep3B }\end{array}$ & $\begin{array}{l}\text { Sensitized } \\
\text { doxorubicin-induced } \\
\text { cancer cell death }\end{array}$ & $\begin{array}{l}\text { Inhibited autophagy } \\
\text { possibly by blocking } \\
\text { lysosomal function via } \\
\text { regulating gene expression } \\
\text { such as CHOP }\end{array}$ & (74) \\
\hline Doxorubicin & & $\begin{array}{l}\text { In vivo } \\
\text { in vitro }\end{array}$ & CMEC & $\begin{array}{l}\text { Suppressed doxorubicin } \\
\text { induced cardiotoxicity }\end{array}$ & $\begin{array}{l}\text { Improved cardiac } \\
\text { function and endothelial } \\
\text { dysfunction at least } \\
\text { partially by activating } \\
\text { the Nrf2/ARE } \\
\text { and Akt pathway }\end{array}$ & (63) \\
\hline Gemcitabine & $\begin{array}{l}\text { Lung } \\
\text { cancer }\end{array}$ & In vivo & & $\begin{array}{l}\text { Inhibited gemcitabine } \\
\text { induced side-effects, } \\
\text { enhanced each other's } \\
\text { antitumor activity }\end{array}$ & Not investigated & (18) \\
\hline
\end{tabular}


Table II. Continued.

\begin{tabular}{|c|c|c|c|c|c|c|}
\hline Drug & Cancer & Observation & Cell type & Activity & Mechanisms & Refs. \\
\hline $\begin{array}{l}\text { Paclitaxel and } \\
\text { cisplatin }\end{array}$ & $\begin{array}{l}\text { Esophageal } \\
\text { squamous cell } \\
\text { carcinoma }\end{array}$ & In vivo & & $\begin{array}{l}\text { Enhanced the } \\
\text { antitumor efficacy } \\
\text { of chemotherapy }\end{array}$ & $\begin{array}{l}\text { Lowered the tumor } \\
\text { microvascular density } \\
\text { and the Ki- } 67 \text { expression }\end{array}$ & (66) \\
\hline Paclitaxel & Breast cancer & $\begin{array}{l}\text { In vitro } \\
\text { in vivo }\end{array}$ & Caco-2 & $\begin{array}{l}\text { Increased the } \\
\text { bioavailability } \\
\text { and antitumor } \\
\text { effect of paclitaxel } \\
\text { lowered paclitaxel } \\
\text { induced toxicity }\end{array}$ & $\begin{array}{l}\text { Inhibited P-gp in tumor } \\
\text { tissue, accelerated } \\
\text { the distribution of } \\
\text { paclitaxel to tissues } \\
\text { and avoided a high } \\
\text { plasma concentration }\end{array}$ & $(67)$ \\
\hline TRAIL & $\begin{array}{l}\text { Hepatocellular } \\
\text { carcinoma }\end{array}$ & $\begin{array}{l}\text { In vitro } \\
\text { in vivo }\end{array}$ & $\begin{array}{l}\text { HepG2, } \\
\text { SK-Hep1, } \\
\text { Huh-7, } \\
\text { Hep3B }\end{array}$ & $\begin{array}{l}\text { Sensitized } \\
\text { TRAIL-induced } \\
\text { HCC cell apoptosis }\end{array}$ & $\begin{array}{l}\text { Increased of TRAIL } \\
\text { receptors DR5 expression } \\
\text { by CHOP upregulation }\end{array}$ & (73) \\
\hline
\end{tabular}

$\mathrm{CP}$, cyclophosphamide; CMEC, cardiac microvascular endothelial cells; HO-1/(NQO)-1, heme oxygenase/NAD(P)H quinone oxidoreductase-1; Nrf2/ARE, nuclear factor erythroid 2-related factor/antioxidant response element; TRAIL, TNF related apoptosis-inducing ligand.

Induction of apoptosis. Apoptosis, known as programmed cell death, is one of the principal mechanisms which maintains cellular homeostasis. In human cancers, tumor cells proliferate more rapidly than normal cells and always lose appropriate apoptotic control. This disruption of growth balance can promote tumor development (26). As shown in Table I, Rg3 can induce apoptosis via two major pathways: the mitochondrial-dependent intrinsic apoptotic pathway and the death receptor-dependent extrinsic pathway. Mitochondrialdependent apoptosis involves a reduction in mitochondrial membrane potential, which results in the release of cytochrome $c$ from the mitochondria, and the activation of caspase-9 and caspase-3, and finally, apoptosis (27). It has been shown that 20(S)-ginsenoside $\mathrm{Rg} 3$-induced apoptosis is dependent on the activation of caspase- 3 and caspase- 9 , which is mediated by the PI3K pathway in HO-8910 human ovarian cancer cells (28). Reactive oxygen species (ROS) and Bcl-2 family members play an important role in the mitochondrial apoptotic pathway. Ginsenoside Rg3 has been shown to activate intracellular ROS generation and/or increase the ratio of Bax to $\mathrm{Bcl}-2$ protein to induce mitochondrial-dependent apoptosis (16,29-33). p53 and nuclear factor $(\mathrm{NF})-\kappa \mathrm{B}$, two nuclear transcription factors, play a critical role in mitochondrial membrane potential through the regulation of the expression of apoptosis-related genes, such as inhibitors of apoptosis proteins (IAPs), X-linked inhibitor of apoptosis protein (XIAP) and Bcl-2. p53 is an important proapoptotic factor, while NF- $\kappa \mathrm{B}$ is a type of anti-apoptotic factor. 20(S)-ginsenoside $\operatorname{Rg} 3$ exerts cytotoxic effects by activating the p53 pathway and subsequently inducing mitochondrialdependent apoptosis (34). Moreover, ginsenoside $\mathrm{Rg} 3$ has been shown to inhibit mutant p53 and NF- $\mathrm{B}$ signaling, possibly via the inactivation of extracellular signal-regulated kinase (ERK) and Akt to activate the mitochondrial death pathway, including the reduction of the ratio of $\mathrm{Bcl}-2 / \mathrm{Bax}$ expression, the disruption of mitochondrial membrane potential, the activation of caspase-3 and ROS generation (17,35). p53 and Bax have also been shown to play a role in the $20(S)$ - $\mathrm{Rg} 3$-induced apoptosis of
HT-29 colon cancer cells via the activation of 5' AMP-activated protein kinase (36).

The extrinsic apoptotic pathway is activated by specific ligands, such as Fas ligand, tumor necrosis factor- $\alpha$ (TNF- $\alpha$ ), and tumor necrosis factor-related apoptosis-inducing ligand (TRAIL). These receptors can activate a caspase8 -dependent cascade to induce apoptosis (21). Another previous study demonstrated that ginsenoside $\mathrm{Rg} 3$ induced apoptosis through the activation of caspase- 8 in the human gastric cancer cell line, AGS (37). The increased expression of Fas has also been observed in Rg3-treated A549 cells (15). In addition, the occurence of extrinsic apoptosis with the activation of endoplasmic reticulum stress mediates ginseng $\mathrm{Rg} 3$-induced apoptosis (38).

In addition, ion channels are crucial to tumor growth and cancer cell survival. Kim et al suggested that the blockade of TRPM7 channels played an important role in the Rg3-induced apoptosis of AGS cells, a human gastric adenocarcinoma cell line (39).

Inhibition of proliferation. Ginsenoside $\mathrm{Rg} 3$ has been shown to exert significant inhibitory effects on cancer cell proliferation. In LNCaP and PC3 human prostate carcinoma cell lines, 20(S)-ginsenoside Rg3 was shown to exhibit good growth inhibitory activity, which may be associated with the modulation of mitogen-activated protein (MAP) kinases (40). Rg3 inhibited EGFR activation and its downstream signal transduction to suppress the growth and proliferation of lung cancer cells A549 (15). Another study on melanoma suggested that 20(R)-ginsenoside Rg3 inhibited cancer cell proliferation by the deactivation of EGFR and the decrease of fucosyltransferase IV (FUT4)/Lewis Y (LeY) expression (41). In addition, the protein expression of proliferating cell nuclear antigen (PCNA), serine/threonine kinase receptor associated protein (STRAP) and that of proteins related to mitosis and DNA repair was shown to be suppressed in 20(S)-ginsenoside $\mathrm{Rg} 3$-treated human colon cancer cell lines (42). Ginsenoside $\operatorname{Rg} 3$ has also been shown 
to inhibit the nuclear translocation of $\beta$-catenin, an oncogene, and the proliferation of colon cancer cell lines (43). Microarray hybridization analysis has shown $20(S)$-ginsenoside $\mathrm{Rg} 3$ inhibits the proliferation of HCT116 cells, mostly by regulating the Eph/ephrin pathway and the gene expression of anchor protein 8-like (AKAPA8L) and phosphatidylinositol transfer protein alpha (PITPNA) (44). Additionally, chronic treatment with 20(S)-ginsenoside $\mathrm{Rg} 3$ at a sub-apoptotic concentration has been shown to induce senescence-like growth arrest in human glioma cells through the Akt and p53/p21 pathways (45).

Cell cycle arrest involves a set of events, resulting in cell growth inhibition. 20(S)-ginsenoside $\mathrm{Rg} 3$ has been shown to have an anti-proliferative activity in MCF-7 human breast cancer cells by arresting the cell cycle at the G1-phase (46). p53, a tumor suppressor, plays an important role in mediating cell cycle arrest and the DNA damage response or apoptosis, as well as p21, a cell cycle inhibitor, downstream of p53. 20(S)-ginsenoside $\mathrm{Rg} 3$ has been found to have the ability to inhibit mouse double minute 2 homolog (MDM2), a negative regulator of $\mathrm{p} 53$, to activate the $\mathrm{p} 53 / \mathrm{p} 21$ pathway and subsequently induce cycle arrest at the $G_{0} / G_{1}$ phase in gallbladder cancer cells (34). Moreover, was previously demonstrated that in both A375 and C816 melanoma cell lines, 20(R)-ginsenoside $\mathrm{Rg} 3$ inhibited proliferation and induced cell cycle arrest at the $G_{0} / G_{1}$ phase by decreasing the expression of histone deacetylase (HDAC) 3 and increasing p53 acetylation and transcriptional activity (47).

Inhibition of metastasis. Metastasis is a complex process through which cancer cells spread from a primary site to form tumors at other distant parts of the body. Tumor metastasis is a major cause of tumor recurrence and mortality, in many types of cancer, such as breast cancer (48). Matrix metalloproteinases (MMPs), which can degrade the extracellular matrix and basement membrane, play an important role in tumor metastasis, and MMP-2 and MMP-9 are of particular importance in these events (49). As previously demonstrated, the Rg3-induced downregulation of MMP-9 appears to be associated with the decreased invasive capacity of SKOV-3 ovarian cancer cells (50). The suppression of MMP-13 by the p38 MAP kinase signaling pathway has been shown to play a role in the inhibition of the metastasis of B16F10 cells by 20(S)-ginsenoside $\mathrm{Rg} 3$ in (51). In addition, ginsenoside $\mathrm{Rg} 3$ has been shown to inhibit the migration of SW480 colon cancer cells by suppressing NF- $\kappa \mathrm{B}$ activity and the expression of NF- $\kappa \mathrm{B}$-regulated gene products, including MMP-9, cyclooxygenase (COX)-2 and c-Myc (52).

EMT is also an important mechanism involved in cancer metastasis. 20(R)-ginsenoside $\mathrm{Rg} 3$ and 20(S)-ginsenoside $\mathrm{Rg} 3$ possess the ability to inhibit tumor metastasis by the suppression of EMT. In a previous study, 20(R)-ginsenoside $\mathrm{Rg} 3$ suppressed lung cancer migration or/and invasion by inhibiting TGF- $\beta 1$-induced EMT accompanied by the inactivation of MMP-2, p38 MAPK and Smad2 (53). In another study, 20(S)-ginsenoside Rg3 effectively suppressed hypoxia-induced EMT, inhibiting ovarian cancer metastasis (54).

In the breast cancer cell line, MDA-MB-231, 20(S)-ginsenoside $\mathrm{Rg} 3$ was reported to exert anti-metastatic effects by inhibiting the expression of $\mathrm{C}-\mathrm{X}-\mathrm{C}$ chemokine receptor type 4 (CXCR4), which is a vital molecule in migration (48).
Moreover, 20(S)-ginsenoside $\operatorname{Rg} 3$ has been shown to decrease the incidence of metastasis by inhibiting the expression of aquaporin 1 (AQP1) in PC-3M prostate cancer cells (55).

Inhibition of angiogenesis. Tumor angiogenesis is a process involving the formation of new blood vessels, which is essential to tumor growth and metastasis by supplying oxygen and nutrients. $\operatorname{Rg} 3$ has been found to inhibit tumor angiogenesis via the suppression of vascular endothelial growth factor (VEGF) expression by blocking multiple hypoxia-induced and angiogenesis-related signaling pathways in the human esophageal carcinoma cell line, Eca-109, and in the renal cell carcinoma cell line, 786-0 cells (56). In addition, both in vitro and in vivo experiments have demonstrated that 20(R)-ginsenoside $\mathrm{Rg} 3$ significantly inhibits human umbilical vein endothelial cell (HUVEC) proliferation and VEGF- and basic fibroblast growth factor (bFGF)-stimulated angiogenesis (57). Endothelial progenitor cells (EPCs) are closely related to tumor angiogenesis by promoting angiogenic factors, such as VEGF. In human umbilical cord blood (hUCB)-derived CD34-positive stem cells, treatment with $\mathrm{Rg} 3$ was shown to inhibit EPC differentiation and tube formation via the VEGF-dependent Akt/endothelial nitric oxide synthase (eNOS) signaling pathway (58). Rg3 also was found to effectively inhibit EPC proliferation and VEGF-induced angiogenesis in vivo through multiple signaling cascades, such as p38 MAP kinase (59).

Furthermore, vasculogenic mimicry (VM), a novel tumor microcirculation system different from classical endothelium-dependent angiogenesis, plays a critical role in tumor progression. Guo et al found that ginsenoside $\mathrm{Rg} 3$ effectively inhibited VM formation in pancreatic cancer by inhibiting the expression of particular genes, including VE-cadherin, EphA2, MMP-2 and MMP-9, both in vitro and in tumor xenografts (60).

Inhibition of multidrug resistance (MDR) and increase of chemosensitivity. Some studies have suggested that combination treatment may be more lead to an improved treatment efficacy with decreased toxicity by exerting synergistic effects, although the exact mechanisms involved remain unclear $(18,61)$. For example, $\mathrm{As}_{2} \mathrm{O}_{3}$ in combination with $\mathrm{Rg} 3$ has been shown to significantly inhibit NCI-H1299 lung cancer cell proliferation and to prolong the survival of tumor-bearing mice (62). $\mathrm{Rg} 3$ has been shown to suppress doxorubicin-induced cardio-toxicity both in vitro and in vivo, possibly by activating the NF-E2related factor 2 (Nrf2)/antioxidant responsive element (ARE). and PI3/Akt pathways (63). 20(S)-ginsenoside Rg3 has also been shown to protect normal cells against cyclophosphamide (CP)-induced genotoxity through antioxidant activity (6). In Lewis lung carcinoma and ovarian cancer models, the co-administration of ginsenoside $\mathrm{Rg} 3$ was shown to effectively enhance the inhibitory effects of $\mathrm{CP}$ on tumors and to reduce the occurrence of side-effects $(64,65)$. Ginsenoside $\mathrm{Rg} 3$ has also been shown to improve the antitumor activity of paclitaxel and cisplatin in an animal model of esophageal squamous cell carcinoma (66). In addition, 20(S)-ginsenoside $\mathrm{Rg} 3$ increases the oral bioavailability of paclitaxel and then improves the antitumor activity of paclitaxel (67).

$\mathrm{Rg} 3$ enhances the chemosensitivity of cancer cells to chemical drugs or/and can help cells to overcome MDR, which may partly explain the mechanisms of combination therapy. 


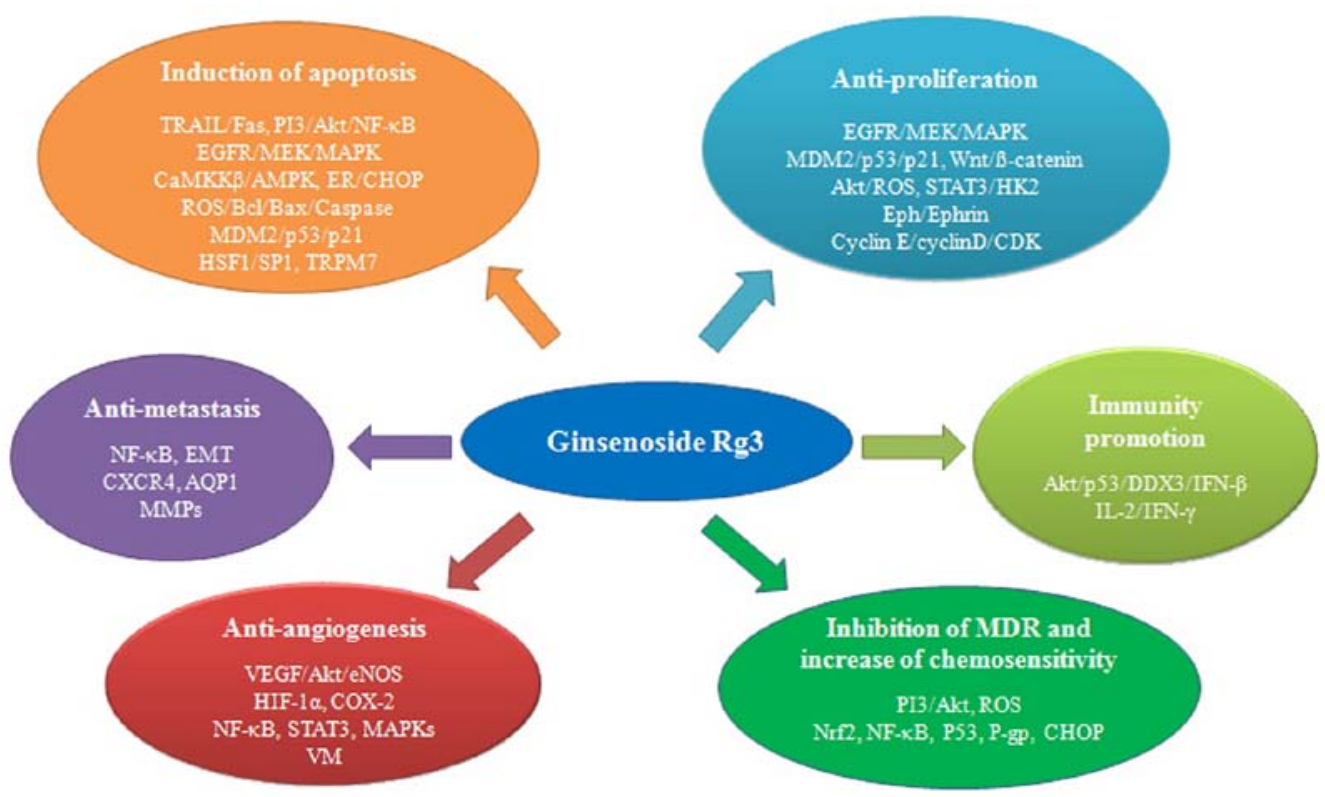

Figure 2. Possible antitumor mechanisms of ginsenoside Rg3. CDKs, cyclin-dependent kinases.

Previous studies have indicated that 20(S)-ginsenoside $\mathrm{Rg} 3$ is a highly effective modulating agent in reversing MDR in drug-resistant P388 leukemia cells and human fibrocarcinoma KBV20C cells specifically $(68,69)$. Combination therapy using $\mathrm{Rg} 3$ and the conventional chemotherapeutic agent, docetaxel, has been shown to significantly enhance the sensitivity of cancer cells and to decrease drug resistance in prostate cancer and colon cancer cells via the inhibition of NF- $\kappa \mathrm{B}(70,71)$. Moreover, $\operatorname{Rg} 3$ has been shown to enhance the susceptibility of the colon to cisplatin by inhibiting HO-1/NQO-1 expression. Moreover, $\operatorname{Rg} 3$ also decreased cisplatin-induced tissue damage in the kidneys and liver by preventing cisplatin-induced intracellular ROS generation (72). 20(S)-ginsenoside Rg3 has also been shown to increase TRAIL receptor DR5 expression and sensitivity to TRAIL in hepatocellular carcinoma (HCC) cells, such as HepG2 (73). 20(S)-ginsenoside Rg3 is also capable of sensitizing doxorubicin-treated liver cancer cells death by inhibiting doxorubicin-induced autophagy possibly by blocking lysosomal function (74).

Promotion of immunity. $\mathrm{Rg} 3$ also plays a role in the improvement of host immunity in tumor-bearing animal models. A previous study suggested that a ginsenoside Rg3-fortified red ginseng preparation significantly suppressed tumor growth in H460 tumor-bearing mice by immunopotentiation (75). In addition, treatment with $\mathrm{Rg} 3$, has been shown to markedly enhance $(\mathrm{P}<0.05)$ cellular immunity by stimulating ConA-induced lymphocyte proliferation and the secretion of cytokines [interleukin (IL)-2, interferon (IFN)- $\gamma$ ] in the immune organs and serum of hepatoma $\mathrm{H} 22$-bearing mice (76). Moreover, $\operatorname{Rg} 3$ has been shown to augment innate immunity and IFN- $\beta$ expression via the upregulation of DDX3 and the activation of the TANK-binding kinase 1 (TBK1)/inhibitor- $\kappa \mathrm{B}$ kinase $\varepsilon(\mathrm{IKK} \varepsilon)$ /interferon regulatory factor 3 (IRF3) pathway (77). Therefore, $\operatorname{Rg} 3$ may be a potent immunomodulatory candidate for the treatment of cancer.

\section{Clinical studies}

Although many studies have demonstrated a clear anticancer activity of $\operatorname{Rg} 3$ in various cancer cell lines or/and xenograft tumor models, the efficacy of $\mathrm{Rg} 3$ in human cancer requires further investigation. Shenyi capsule (ginsenoside Rg3 monomer preparation), a class I new drug in traditional Chinese medicine, is being used clinically in the treatment of various types of cancer, such as lung cancer, breast cancer and gastrointestinal tumors in China (78). A prospective, randomized, controlled study using 133 non-small cell lung cancer cases suggested that Shenyi capsule, particularly in combination with chemotherapy, improved the post-operative lifespan of patients mainly by enhancing the immune function and inhibiting angiogensis (79). Another randomized trial of 60 advanced esophageal cancer cases found that the combination of chemotherapy with Shenyi capsule was effective in improving the quality of life of patients and 1 year survival rates. In addition, a meta-analysis involving 274 female breast cancer patients in China also showed that the combination treatment group exhibited significantly attenuated leucopenia. However, there were no significant differences in the total response rate compared with the chemotherapy groups $(80,81)$.

In general, the published clinical studies suggested that Rg3 was a good antitumor agent by improving the immune function and the quality of life of cancer patients. However, there has been no strong evidence to confirm the efficacy of $\mathrm{Rg} 3$. Further, large controlled and highly qualified clinical trials are required in order to better guide clinical applications.

\section{Conclusions}

Ginsenoside Rg3 displays significant antitumor activities in several types of cancer both in vitro and in vivo. The molecular mechanisms of tumor inhibition employed by ginsenoside Rg3 mainly involve the induction of apoptosis, and the inhibition 
of proliferation, metastasis and angiogensis, and the promotion of immunity (Fig. 2). Furthermore, experiments have demonstrated that $\mathrm{Rg} 3$ is relatively safe for use in the marrow, heart, lung, liver, kidney and nervous system (82). Long-term toxicological studies on beagle dogs and rats also confirmed that 20(S)-ginsenoside $\operatorname{Rg} 3$ was non-toxic and well-tolerated $(83,84)$. Ginsenoside Rg3 has also been shown to significantly decrease some environmental carcinogen-induced DNA damage, such as N-methyl-N'-nitro-N-nitrosoguanidine (MNNG) and benzo[a] pyrene $(85,86)$. These results make ginsenoside $\mathrm{Rg} 3$ an attractive candidate for cancer prevention. Combination therapy with conventional cancer treatments, such as chemotherapy and surgery has been suggested to be more effective. $\operatorname{Rg} 3$ improves the chemosensitivity of tumor cells to chemical drugs, reverses MDR and decreases toxicity. Additionally, Rg3 combined with TAE, more effectively inhibits tumor growth. Apart from these, a recent study found that $20(S)$-ginsenoside $\mathrm{Rg} 3$ induced the apoptosis of HepG2 cells, accompanied by the induction of autophagy via mitochondrial and $\mathrm{Ca}^{2+}$-related pathways, which decreased the survival of cancer cells. Thus, co-treatment with autophagy inhibitors and $\operatorname{Rg} 3$ would be beneficial (87). Clinical trials still demonstrate that ginsenoside $\operatorname{Rg} 3$ is an effective antitumor agent. Therefore, ginsenoside $\operatorname{Rg} 3$ is gaining more attention as an anticancer drug due to its favorable safety and efficacy.

However, there are still several aspects limiting the use of Rg3: i) its mechanisms of action have not yet been fully established. For example, ginsenoside Rg3 induces strong genotoxicity and DNA damage in human osteosarcoma cells. However, whether these genotoxic effects are directly associated with cell cycle arrest and apoptosis is not clear (85). Further studies are warranted to determine the mechanisms through which the different signaling pathways are orchestrated and and those through which the synergistic antitumor activities of ginsenosides and conventional cancer treatments are realized in order to fully understand the benefits of Rg3. ii) Its poor aqueous solubility and low oral bioavailability (88). Although studies have been performed to explore a method to solve this problem, for example, 20(S)-ginsenoside Rg3-loaded magnetic human serum albumin nanospheres [20(S)-Rg3/HSAMNP] were created and were shown to markedly enhance the efficiency of HeLa cervical cancer cell inhibition when combined with hyperthermia (89), and liposomal ginsenoside Rg3 showed increased anticancer activity in vitro compared to the $\mathrm{Rg} 3$ solution (90), it is necessary to evaluate the efficacy of these optimized therapy in vivo. It may be possible to develop novel Rg3 analogues with improved efficacy, pharmacokinetics and bioavailability profiles. iii) Currently, the evidence of $\operatorname{Rg} 3$ efficacy is not yet conclusive in humans. There is a significant need to perform further, larger cohort clinical studies to confirm its efficacy for better application in the clinic.

In conclusion, $\mathrm{Rg} 3$ has great potential for use as a broad-spectrum anticancer drug and an effective adjuvant to cancer therapies in the future.

\section{Acknowledgements}

This study was supported by funds from the National Natural Science Foundation of China (81502515 and 81503332), Shanghai Natural Science Foundation (no. 13ZR1431900),
Shanghai Municipal Health and Family Planning Commission (nos. 20134173, 20134090 and ZYXK2012010), Key Disciplines Group Construction Project of Pudong Health Bureau of Shanghai (no. PWZxq2014-12), and the Open Research Fund of State Key Laboratory Breeding Base of Systematic Research, Development and Utilization of Chinese Medicine Resources (no. ME2016012).

\section{References}

1. Torre LA, Bray F, Siegel RL, Ferlay J, Lortet-Tieulent J and Jemal A: Global cancer statistics, 2012. CA Cancer J Clin 65: 87-108, 2015.

2. Stewart B and Wild C: World Cancer Report 2014. International Agency for Research on Cancer. World Health Organization, Lyon, France, 2014.

3. Cabrera R and Nelson DR: Review article: the management of hepatocellular carcinoma. Aliment Pharmacol Ther 31: 461-476, 2010.

4. Fletcher A, Choudhury A and Alam N: Metastatic bladder cancer: a review of current management. ISRN Urol 2011: 545241, 2011.

5. Baldo BA and Pham NH: Adverse reactions to targeted and non-targeted chemotherapeutic drugs with emphasis on hypersensitivity responses and the invasive metastatic switch. Cancer Metastasis Rev 32: 723-761, 2013.

6. Zhang QH, Wu CF, Duan L and Yang JY: Protective effects of ginsenoside $\operatorname{Rg}(3)$ against cyclophosphamide-induced DNA damage and cell apoptosis in mice. Arch Toxicol 82: 117-123, 2008.

7. Lü JM, Yao Q and Chen C: Ginseng compounds: an update on their molecular mechanisms and medical applications. Curr Vasc Pharmacol 7: 293-302, 2009.

8. Liu L, Zhu XM, Wang QJ, Zhang DL, Fang ZM, Wang CY, Wang Z, Sun BS, Wu H and Sung CK: Enzymatic preparation of $20(\mathrm{~S}, \mathrm{R})$-protopanaxadiol by transformation of $20(\mathrm{~S}, \mathrm{R})-\mathrm{Rg} 3$ from black ginseng. Phytochemistry 71: 1514-1520, 2010.

9. Gum SI and Cho MK: The amelioration of N-acetyl-p-benzoquinone imine toxicity by ginsenoside $\mathrm{Rg} 3$ : the role of Nrf2-mediated detoxification and Mrp1/Mrp3 transports. Oxid Med Cell Longev 2013: 957947, 2013.

10. He B, Chen P, Yang J, Yun Y, Zhang X, Yang R and Shen Z: Neuroprotective effect of $20(\mathrm{R})$-ginsenoside $\operatorname{Rg}(3)$ against transient focal cerebral ischemia in rats. Neurosci Lett 526: 106-111, 2012.

11. Kwok HH, Guo GL, Lau JK, Cheng YK, Wang JR, Jiang ZH, Keung MH, Mak NK, Yue PY and Wong RN: Stereoisomers ginsenosides-20(S)-Rg3 and -20(R)-Rg3 differentially induce angiogenesis through peroxisome proliferator-activated receptor-gamma. Biochem Pharmacol 83: 893-902, 2012.

12. Wei X, Chen J, Su F, Su X, Hu T and Hu S: Stereospecificity of ginsenoside $\mathrm{Rg} 3$ in promotion of the immune response to ovalbumin in mice. Int Immunol 24: 465-471, 2012.

13. Xu Y, Zhang P, Wang C, Shan Y, Wang D, Qian F, Sun M and Zhu C: Effect of ginsenoside Rg3 on tyrosine hydroxylase and related mechanisms in the forced swimming-induced fatigue rats. J Ethnopharmacol 150: 138-147, 2013.

14. Wei X, Su F, Su X, Hu T and Hu S: Stereospecific antioxidant effects of ginsenoside $\mathrm{Rg} 3$ on oxidative stress induced by cyclophosphamide in mice. Fitoterapia 83: 636-642, 2012.

15. Joo EJ, Chun J, Ha YW, Ko HJ, Xu MY and Kim YS: Novel roles of ginsenoside $\mathrm{Rg} 3$ in apoptosis through downregulation of epidermal growth factor receptor. Chem Biol Interact 233: 25-34, 2015.

16. Park HM, Kim SJ, Kim JS and Kang HS: Reactive oxygen species mediated ginsenoside $\mathrm{Rg} 3$ - and $\mathrm{Rh} 2$-induced apoptosis in hepatoma cells through mitochondrial signaling pathways. Food Chem Toxicol 50: 2736-2741, 2012.

17. Kim BM, Kim DH, Park JH, Na HK and Surh YJ: Ginsenoside Rg3 induces apoptosis of human breast cancer (MDA-MB-231) cells. J Cancer Prev 18: 177-185, 2013.

18. Liu TG, Huang Y, Cui DD, Huang XB, Mao SH, Ji LL, Song HB and Yi C: Inhibitory effect of ginsenoside Rg3 combined with gemcitabine on angiogenesis and growth of lung cancer in mice. BMC Cancer 9: 250, 2009.

19. Kim WY, Kim JM, Han SB, Lee SK, Kim ND, Park MK, Kim CK and Park JH: Steaming of ginseng at high temperature enhances biological activity. J Nat Prod 63: 1702-1704, 2000. 
20. Kim IW, Sun WS, Yun BS, Kim NR, Min D and Kim SK: Characterizing a full spectrum of physico-chemical properties of $(20 S)$ - and $(20 R)$-ginsenoside $\operatorname{Rg} 3$ to be proposed as standard reference materials. J Ginseng Res 37: 124-134, 2013.

21. Nag SA, Qin JJ, Wang W, Wang MH, Wang H and Zhang R: Ginsenosides as anticancer agents: in vitro and in vivo activities, structure-activity relationships, and molecular mechanisms of action. Front Pharmacol 3: 25, 2012.

22. Wani MC, Taylor HL, Wall ME, Coggon P and McPhail AT: Plant antitumor agents. VI. The isolation and structure of taxol, a novel antileukemic and antitumor agent from Taxus brevifolia. J Am Chem Soc 93: 2325-2327, 1971.

23. Yun TK, Lee YS, Lee YH, Kim SI and Yun HY: Anticarcinogenic effect of Panax ginseng C.A. Meyer and identification of active compounds. J Korean Med Sci 16 (Suppl): S6-S18, 2001.

24. Yu Y, Zhang C, Liu L and Li X: Hepatic arterial administration of ginsenoside Rg3 and transcatheter arterial embolization for the treatment of VX2 liver carcinomas. Exp Ther Med 5: 761-766, 2013.

25. Amelio I, Melino G and Knight RA: Cell death pathology: cross-talk with autophagy and its clinical implications. Biochem Biophys Res Commun 414: 277-281, 2011.

26. Hanahan D and Weinberg RA: Hallmarks of cancer: the next generation. Cell 144: 646-674, 2011.

27. Karmakar S, Banik NL, Patel SJ and Ray SK: Curcumin activated both receptor-mediated and mitochondria-mediated proteolytic pathways for apoptosis in human glioblastoma T98G cells. Neurosci Lett 407: 53-58, 2006.

28. Wang JH, Nao JF, Zhang M and He P: 20(s)-ginsenoside Rg3 promotes apoptosis in human ovarian cancer HO-8910 cells through PI3K/Akt and XIAP pathways. Tumour Biol 35: 11985-11994, 2014.

29. Jiang JW, Chen XM, Chen XH and Zheng SS: Ginsenoside Rg3 inhibit hepatocellular carcinoma growth via intrinsic apoptotic pathway. World J Gastroenterol 17: 3605-3613, 2011

30. Choi YJ, Lee HJ, Kang DW, Han IH, Choi BK and Cho WH: Ginsenoside Rg3 induces apoptosis in the U87MG human glioblastoma cell line through the MEK signaling pathway and reactive oxygen species. Oncol Rep 30: 1362-1370, 2013.

31. Chen J, Peng H, Ou-Yang X and He X: Research on the antitumor effect of ginsenoside Rg3 in B16 melanoma cells. Melanoma Res 18: 322-329, 2008.

32. Park EH, Kim YJ, Yamabe N, Park SH, Kim HK, Jang HJ, Kim JH, Cheon GJ, Ham J and Kang KS: Stereospecific anticancer effects of ginsenoside $\mathrm{Rg} 3$ epimers isolated from heat-processed American ginseng on human gastric cancer cell. J Ginseng Res 38: 22-27, 2014.

33. Zhang C, Liu L, Yu Y, Chen B, Tang C and Li X: Antitumor effects of ginsenoside $\operatorname{Rg} 3$ on human hepatocellular carcinoma cells. Mol Med Rep 5: 1295-1298, 2012.

34. Zhang F, Li M, Wu X, Hu Y, Cao Y, Wang X, Xiang S, Li H, Jiang L, Tan Z, et al: 20(S)-ginsenoside Rg3 promotes senescence and apoptosis in gallbladder cancer cells via the p53 pathway. Drug Des Devel Ther 9: 3969-3987, 2015.

35. Kim BM, Kim DH,Park JH, Surh YJ and Na HK: Ginsenoside Rg3 inhibits constitutive activation of $\mathrm{NF}-\kappa \mathrm{B}$ signaling in human breast cancer (MDA-MB-231) cells: ERK and Akt as potential upstream targets. J Cancer Prev 19: 23-30, 2014.

36. Yuan HD, Quan HY, Zhang Y, Kim SH and Chung SH: 20(S)-ginsenoside Rg3-induced apoptosis in HT-29 colon cancer cells is associated with AMPK signaling pathway. Mol Med Rep 3: 825-831, 2010.

37. Aziz F, Wang X, Liu J and Yan Q: Ginsenoside Rg3 induces FUT4-mediated apoptosis in $H$. pylori CagA-treated gastric cancer cells by regulating SP1 and HSF1 expressions. Toxicol In Vitro 31: 158-166, 2016

38. Wu K, Li N, Sun H, Xu T, Jin F and Nie J: Endoplasmic reticulum stress activation mediates Ginseng $\mathrm{Rg} 3$-induced anti-gallbladder cancer cell activity. Biochem Biophys Res Commun 466 : 369-375, 2015

39. Kim BJ, Nah SY, Jeon JH, So I and Kim SJ: Transient receptor potential melastatin 7 channels are involved in ginsenoside Rg3-induced apoptosis in gastric cancer cells. Basic Clin Pharmacol Toxicol 109: 233-239, 2011.

40. Kim HS, Lee EH, Ko SR, Choi KJ, Park JH and Im DS: Effects of ginsenosides $\mathrm{Rg} 3$ and $\mathrm{Rh} 2$ on the proliferation of prostate cancer cells. Arch Pharm Res 27: 429-435, 2004

41. Shan X, Aziz F, Tian LL, Wang XQ, Yan Q and Liu JW: Ginsenoside Rg3-induced EGFR/MAPK pathway deactivation inhibits melanoma cell proliferation by decreasing FUT4/LeY expression. Int J Oncol 46: 1667-1676, 2015.
42. Lee SY, Kim GT, Roh SH, Song JS, Kim HJ, Hong SS, Kwon SW and Park JH: Proteomic analysis of the anti-cancer effect of 20S-ginsenoside Rg3 in human colon cancer cell lines. Biosci Biotechnol Biochem 73: 811-816, 2009.

43. He BC, Gao JL, Luo X, Luo J, Shen J, Wang L, Zhou Q, Wang YT, Luu HH, Haydon RC, et al: Ginsenoside Rg3 inhibits colorectal tumor growth through the down-regulation of $\mathrm{Wnt} / \beta$-catenin signaling. Int J Oncol 38: 437-445, 2011.

44. Luo X, Wang CZ, Chen J, Song WX, Luo J, Tang N, He BC, Kang Q, Wang Y, Du W, et al: Characterization of gene expression regulated by American ginseng and ginsenoside Rg3 in human colorectal cancer cells. Int J Oncol 32: 975-983, 2008.

45. Sin S, Kim SY and Kim SS: Chronic treatment with ginsenoside $\mathrm{Rg} 3$ induces Akt-dependent senescence in human glioma cells. Int J Oncol 41: 1669-1674, 2012.

46. Wang CZ, Aung HH, Zhang B, Sun S, Li XL, He H, Xie JT, He TC, Du W and Yuan CS: Chemopreventive effects of heat-processed Panax quinquefolius root on human breast cancer cells. Anticancer Res 28: 2545-2551, 2008.

47. Shan X, Fu YS, Aziz F, Wang XQ, Yan Q and Liu JW: Ginsenoside Rg3 inhibits melanoma cell proliferation through down-regulation of histone deacetylase 3 (HDAC3) and increase of p53 acetylation. PLoS One 9: e115401, 2014.

48. Chen XP, Qian LL, Jiang H and Chen JH: Ginsenoside Rg3 inhibits CXCR4 expression and related migrations in a breast cancer cell line. Int J Clin Oncol 16: 519-523, 2011.

49. Deryugina EI and Quigley JP: Matrix metalloproteinases and tumor metastasis. Cancer Metastasis Rev 25: 9-34, 2006.

50. Xu TM, Cui MH, Xin Y, Gu LP, Jiang X, Su MM, Wang DD and Wang WJ: Inhibitory effect of ginsenoside Rg3 on ovarian cancer metastasis. Chin Med J (Engl) 121: 1394-1397, 2008.

51. Lee SG, Kang YJ and Nam JO: Anti-metastasis effects of ginsenoside Rg3 in B16F10 Cells. J Microbiol Biotechnol 25: 1997-2006, 2015.

52. Junmin S, Hongxiang L, Zhen L, Chao Y and Chaojie W: Ginsenoside Rg3 inhibits colon cancer cell migration by suppressing nuclear factor kappa B activity. J Tradit Chin Med 35: 440-444, 2015

53. Kim YJ, Choi WI, Jeon BN, Choi KC, Kim K, Kim TJ, Ham J, Jang HJ, Kang KS and Ko H: Stereospecific effects of ginsenoside $20-\operatorname{Rg} 3$ inhibits TGF- 31 -induced epithelial-mesenchymal transition and suppresses lung cancer migration, invasion and anoikis resistance. Toxicology 322: 23-33, 2014

54. Liu T, Zhao L, Zhang Y, Chen W, Liu D, Hou H, Ding L and Li X: Ginsenoside 20(S)-Rg3 targets HIF-1 $\alpha$ to block hypoxia-induced epithelial-mesenchymal transition in ovarian cancer cells. PLoS One 9: e103887, 2014.

55. Pan XY, Guo H, Han J, Hao F, An Y, Xu Y, Xiaokaiti Y, Pan Y and $\mathrm{Li} \mathrm{XJ}$ : Ginsenoside $\mathrm{Rg} 3$ attenuates cell migration via inhibition of aquaporin 1 expression in PC-3M prostate cancer cells. Eur J Pharmacol 683: 27-34, 2012.

56. Chen QJ, Zhang MZ and Wang LX: Gensenoside Rg3 inhibits hypoxia-induced VEGF expression in human cancer cells. Cell Physiol Biochem 26: 849-858, 2010.

57. Yue PY, Wong DY, Wu PK, Leung PY, Mak NK, Yeung HW, Liu L, Cai Z, Jiang ZH, Fan TP and Wong RN: The angiosuppressive effects of 20(R)- ginsenoside Rg3. Biochem Pharmacol 72: 437-445, 2006

58. Kim JW, Jung SY, Kwon YH, Lee SH, Lee JH, Lee BY and Kwon SM: Ginsenoside Rg3 inhibits endothelial progenitor cell differentiation through attenuation of VEGF-dependent Akt/eNOS signaling. Phytother Res 26: 1286-1293, 2012.

59. Kim JW, Jung SY, Kwon YH, Lee JH, Lee YM, Lee BY and Kwon SM: Ginsenoside Rg3 attenuates tumor angiogenesis via inhibiting bioactivities of endothelial progenitor cells. Cancer Biol Ther 13: 504-515, 2012.

60. Guo JQ, Zheng QH, Chen H, Chen L, Xu JB, Chen MY, Lu D, Wang ZH, Tong HF and Lin S: Ginsenoside Rg3 inhibition of vasculogenic mimicry in pancreatic cancer through downregulation of VE cadherin/EphA2/MMP9/MMP2 expression. Int J Oncol 45: 1065-1072, 2014.

61. Lee YJ, Lee S, Ho JN, Byun SS, Hong SK, Lee SE and Lee E: Synergistic antitumor effect of ginsenoside $\mathrm{Rg} 3$ and cisplatin in cisplatin resistant bladder tumor cell line. Oncol Rep 32: 1803-1808, 2014

62. Che JB, Liu ZH, Ma HB, Li Y, Zhao H, Li XH, Liu WC and Shi GN: Influence of $\mathrm{As}_{2} \mathrm{O}_{3}$ combined with ginsenosides $\mathrm{Rg} 3$ on inhibition of lung cancer NCI-H1299 cells and on subsistence of nude mice bearing hepatoma. Asian Pac J Trop Med 7: $772-775,2014$ 
63. Wang X, Chen L, Wang T, Jiang X, Zhang H, Li P, Lv B and Gao X: Ginsenoside Rg3 antagonizes adriamycin-induced cardiotoxicity by improving endothelial dysfunction from oxidative stress via upregulating the Nrf2-ARE pathway through the activation of akt. Phytomedicine 22: 875-884, 2015.

64. Xu TM, Xin Y, Cui MH, Jiang X and Gu LP: Inhibitory effect of ginsenoside $\mathrm{Rg} 3$ combined with cyclophosphamide on growth and angiogenesis of ovarian cancer. Chin Med J (Engl) 120: 584-588, 2007.

65. Zhang Q, Kang X and Zhao W: Antiangiogenic effect of low-dose cyclophosphamide combined with ginsenoside $\operatorname{Rg} 3$ on Lewis lung carcinoma. Biochem Biophys Res Commun 342: 824-828, 2006.

66. Chang L, Huo B, Lv Y, Wang Y and Liu W: Ginsenoside Rg3 enhances the inhibitory effects of chemotherapy on esophagea squamous cell carcinoma in mice. Mol Clin Oncol 2: 1043-1046, 2014

67. Yang LQ, Wang B, Gan H, Fu ST, Zhu XX, Wu ZN, Zhan DW, Gu RL, Dou GF and Meng ZY: Enhanced oral bioavailability and anti-tumour effect of paclitaxel by 20 (s)-ginsenoside Rg3 in vivo. Biopharm Drug Dispos 33: 425-436, 2012.

68. Kwon HY, Kim EH, Kim SW, Kim SN, Park JD and Rhee DK: Selective toxicity of ginsenoside $\mathrm{Rg} 3$ on multidrug resistant cells by membrane fluidity modulation. Arch Pharm Res 31: 171-177, 2008

69. Park JD, Rhee DK and Lee YH: Biological activities and chemistry of saponins from Panax ginseng C.A. Meyer. Phytochem Rev 4: 159-175, 2005.

70. Kim SM, Lee SY, Cho JS, Son SM, Choi SS, Yun YP, Yoo HS, Yoon DY, Oh KW, Han SB and Hong JT: Combination of ginsenoside $\mathrm{Rg} 3$ with docetaxel enhances the susceptibility of prostate cancer cells via inhibition of NF-kappaB. Eur J Pharmacol 631: 1-9, 2010.

71. Kim SM, Lee SY, Yuk DY, Moon DC, Choi SS, Kim Y, Han SB, Oh KW and Hong JT: Inhibition of NF-kappaB by ginsenoside Rg3 enhances the susceptibility of colon cancer cells to docetaxel. Arch Pharm Res 32: 755-765, 2009.

72. Lee CK, Park KK, Chung AS and Chung WY: Ginsenoside Rg3 enhances the chemosensitivity of tumors to cisplatin by reducing the basal level of nuclear factor erythroid 2-related factor 2 -mediated heme oxygenase-1/NAD $(\mathrm{P}) \mathrm{H}$ quinone oxidoreductase- 1 and prevents normal tissue damage by scavenging cisplatin-induced intracellular reactive oxygen species. Food Chem Toxicol 50: 2565-2574, 2012.

73. Lee JY, Jung KH, Morgan MJ, Kang YR, Lee HS, Koo GB, Hong SS, Kwon SW and Kim YS: Sensitization of TRAIL-induced cell death by 20(S)-ginsenoside Rg3 via CHOP-mediated DR5 upregulation in human hepatocellular carcinoma cells. Mol Cancer Ther 12: 274-285, 2013.

74. Kim DG, Jung KH, Lee DG, Yoon JH, Choi KS Kwon SW, Shen HM, Morgan MJ, Hong SS and Kim YS: 20(S)-Ginsenoside Rg3 is a novel inhibitor of autophagy and sensitizes hepatocellular carcinoma to doxorubicin. Oncotarget 5 : 4438-4451, 2014

75. Park D, Bae DK, Jeon JH, Lee J, Oh N, Yang G, Yang YH, Kim TK, Song J, Lee $\mathrm{SH}$, et al: Immunopotentiation and antitumor effects of a ginsenoside $\mathrm{Rg} 3$-fortified red ginseng preparation in mice bearing H460 lung cancer cells. Environ Toxicol Pharmacol 31: 397-405, 2011.
76. Wu R, Ru Q, Chen L, Ma B and Li C: Stereospecificity of ginsenoside $\mathrm{Rg} 3$ in the promotion of cellular immunity in hepatoma H22-bearing mice. J Food Sci 79: H1430-H1435, 2014

77. Choi YJ, Kang LJ and Lee SG: Stimulation of DDX3 expression by ginsenoside $\mathrm{Rg} 3$ through the Akt/p53 pathway activates the innate immune response via TBK1/IKKe/IRF3 signalling. Curr Med Chem 21: 1050-1060, 2014.

78. Cheng Y and Hua HQ: Clinical research progress in anti-tumor effects of ginesenoside $\mathrm{Rg} 3$. Medical recapitulate 21: 2938-2940, 2015 .

79. Lu P, Su W, Miao ZH, Niu HR, Liu J and Hua QL: Effect and mechanism of ginsenoside Rg3 on postoperative life span of patients with non-small cell lung cancer. Chin J Integr Med 14: 33-36, 2008.

80. Huang JY, Sun Y, Fan QX and Zhang YQ: Efficacy of Shenyi capsule combined with gemcitabine plus cisplatin in treatment of advanced esophageal cancer: a randomized controlled trial. Zhong Xi Yi Jie He Xue Bao 7: 1047-1051, 2009 (In Chinese).

81. Wang XS, Wu Q and Liang L: Combined Shen yi-Jiao nang and chemotherapy in treatment of breast cancer: a systematic review. Pract J Clin Med 9: 192-195, 2012.

82. Coon JT and Ernst E: Panax ginseng: a systematic review of adverse effects and drug interactions. Drug Saf 25: 323-344, 2002.

83. Liu JP, Lu D, Nicholson RC, Li PY and Wang F: Toxicity of a novel anti-tumor agent 20(S)-ginsenoside Rg3: a 26-week intramuscular repeated administration study in Beagle dogs. Food Chem Toxicol 49: 1718-1727, 2011.

84. 83. Liu JP, Lu D, Nicholson RC, Zhao WJ, Li PY and Wang F: Toxicity of a novel anti-tumor agent 20(S)-ginsenoside Rg3: a 26-week intramuscular repeated administration study in rats. Food Chem Toxicol 50: 3388-3396, 2012.

85. Zhang YH, Li HD, Li B, Jiang SD and Jiang LS: Ginsenoside Rg3 induces DNA damage in human osteosarcoma cells and reduces MNNG-induced DNA damage and apoptosis in normal human cells. Oncol Rep 31: 919-925, 2014.

86. Poon PY, Kwok HH, Yue PY, Yang MS, Mak NK, Wong CK and Wong RN: Cytoprotective effect of $20 \mathrm{~S}-\mathrm{Rg} 3$ on benzo[a] pyrene-induced DNA damage. Drug Metab Dispos 40: 120-129, 2012

87. Cheong JH, Kim H, Hong MJ, Yang MH, Kim JW, Yoo H, Yang H, Park JH, Sung SH, Kim HP and Kim J: Stereoisomerspecific anticancer activities of ginsenoside $\operatorname{Rg} 3$ and $\mathrm{Rh} 2$ in HepG2 cells: disparity in cytotoxicity and autophagy-inducing effects due to 20(S)-epimers. Biol Pharm Bull 38: 102-108, 2015.

88. Wang Y, Jin Y, Zhou C, Qu H and Cheng Y: Discovering active compounds from mixture of natural products by data mining approach. Med Biol Eng Comput 46: 605-611, 2008.

89. Yang R, Chen D, Li M, Miao F, Liu P and Tang Q: 20(s)-ginsenoside Rg3-loaded magnetic human serum albumin nanospheres applied to HeLa cervical cancer cells in vitro. Biomed Mater Eng 24: 1991-1998, 2014.

90. Yu H, Teng L, Meng Q, Li Y, Sun X, Lu J, J Lee R and Teng L: Development of liposomal ginsenoside Rg3: formulation optimization and evaluation of its anticancer effects. Int J Pharm 450: 250-258, 2013

91. Li J, Liu T, Zhao L, Chen W, Hou H, Ye Z and Li X: Ginsenoside 20(S) Rg3 inhibits the Warburg effect through STAT3 pathways in ovarian cancer cells. Int J Oncol 46: 775-781, 2015. 